\title{
DETERMINANTS OF ENVIRONMENTAL DISCLOSURE IN ANNUAL REPORTS OF SRI LANKAN LISTED MANUFACTURING COMPANIES
}

\author{
A.M. Inun Jariya \\ Department of Accountancy and Finance \\ South Eastern University of Sri Lanka \\ jariyaam@seu.ac.lk / inunjariya@yahoo.com
}

\begin{abstract}
The aim of this study is to investigate the level of corporate environmental information disclosure practices of listed manufacturing companies in Sri Lanka. The study also examined the influence of firm size, profitability and listing age on the level of corporate environmental information disclosure. To achieve the aims of this study, content analysis and statistical analysis were used. Content analysis by word count is used to determine the level of social and environmental disclosures on annual reports of Sri Lankan listed manufacturing companies. To determine the factors that explain the level of social and environmental information disclosures, descriptive statistics, correlation analysis and multiple regressions analysis were used.
\end{abstract}

The finding indicates that 50.63\% of the companies provided corporate environmental information in their 2012/2013 annual reports. Multiple regression analysis revealed that size of the firm had significant positive relationship with the level of corporate environmental information disclosure. However, corporate environmental disclosure has not been influenced by the profitability and listing age.

Keywords: Corporate Environmental Disclosure, Firm Size, Profitability Listing Age, Manufacturing Industry, Sri Lanka

\section{Introduction}

In recent years environmental disclosure has become more important things in both developing and developed countries. Stakeholders' demand for environmental information and the reporting of firm impact on the physical environment have dramatically increased during the last few years. However, the existing environmental reporting even in developed countries is deficient and not of a standard to satisfy the information requirements of various groups of stakeholders. This is mainly due to an inadequate supply of environmental information as there are impediments to encourage environmental reporting at firm as well as at national level.

Corporate environmental disclosure is a part of social reporting and the environmental disclosures are mainly non-financial in nature. Stakeholders' demand for environmental 
information and the reporting of firm impact on the physical environment have dramatically increased during the last few. Corporate environmental disclosure is increasingly an important issue to corporate investors, public policy makers and the general public. These disclosures are important, because they provide environmental performance information and influence capital markets (Villiers and Staden, 2011). Therefore, corporate investors and other stakeholders need to use environmental information in their decisionmaking. There is extensive evidence that social and environmental information is useful for decision-making by investors and other stakeholders (Blacconiere and Patten, 1994 and Richardson and Welker, 2001). In response to investors' and other stakeholders' concerns about corporate environmental policies, many firms are voluntarily increasing their level of social and environmental disclosure through different sources and media. In this context, Sri Lankan companies also disclose environmental information in their annual reports. But, the patterns of environmental disclosures of the companies are not broadly studied.

Further, it has been argued by the researchers that the level of Corporate Environmental Disclosure is dependent on several corporate attributes. There are studies which empirically examine the extent of environmental disclosure and measure the relationship between environment disclosure and several corporate attributes. However, most of these studies are concerned with developed countries (e.g. Europe, Singapore, South Africa, UK and USA). Very few of studies could be found in the contact of developing countries (e.g.
Bangladesh, Pakistan and India) and no enough such study has been carried out with special reference to Sri Lanka.

The purpose of this study to investigate the level of environmental information disclosure practices on annual reports of companies listed manufacturing companies in Sri Lanka, also to determine the influence of firm size, profitability, and listing age of age on the level of environmental information disclosures under legitimacy theory.

The remainder of this paper is organized as follows: the next section describe the legitimacy theory and reviews of previous research along with hypotheses; section three presents the study sample, data and its analysis and research method is provided in section four; while section five analyses and discusses the research results; finally, the conclusion of the study considered briefly in section six.

\section{Literature View}

\section{Legitimacy theory}

Despite the limited mandatory reporting requirements, the literature on social and environmental accounting suggests that an increasing number of companies are now providing environmental disclosures albeit at varying levels. There are different theoretical frameworks used to explain why companies may provide voluntary disclosure. According to Guthrie and Parker (1990) legitimacy theory is one of the most adopted theories for explaining corporate social and environmental disclosures. Perrow (1970) defines legitimacy as a generalized perception or assumption that the actions of an entity are desirable, 
proper, or appropriate within some socially constructed system of norms, value, beliefs, and definitions. Legitimacy theory has been offered in the literature as a way to explain the firms' environmental disclosure policies (Hogner, 1982; Lindblom, 1983; Patten, 1991, 1992, 2002). This theory revolves around the concept of a social contact. The social contract is an implicit contract with society agreeing "to perform socially desirable actions in return for society's approval of its objectives and its ultimate survival" (Guthrie and Parker, 1989). Therefore, social disclosure can be viewed as a constructed image or symbolic impression of itself that a firm is conveying to the outside world to control its political or economic position (Neu et al., 1998).

Legitimacy theory assumes that voluntary corporate social and environmental disclosures are in response of social, economic and political factors. Many previous studies on corporate social disclosures have provided evidence that firms do voluntarily disclose information in their annual reports as a strategy to manage their legitimacy (e. g. Patten, 1991; Deegan and Rankin, 1996; Woodward et al., 2001).

\section{Prior Studies and Hypotheses Development}

\section{Size of the Firm}

An association between company size and social responsibility was first investigated by Eilbert and Parket (1973). They concluded that large firms feel themselves to be the target of social activists or regulators and thus consider it necessary to make a visible effort to establish their social responsibility credentials to keep their dominance. The legitimacy theory provides a basis for a relationship between level of corporate social disclosures (CSD) and firm size (Hackston and Milne, 1996). Under legitimacy theory, firms' societal existence depends on the acceptance of the society where they operate. Since the firms can be influenced by, and have influences to the society, legitimacy is assumed an important resource determining their survival (Deegan, 2002). It is argued by Guthrie and Parker (1989) and Cowen et al. (1987) that larger companies are scrutinized more by public as compared to small companies. Large companies are therefore under pressure to disclose more social responsibility information as compared to small companies to reduce the pressure of this public scrutiny. They try to obtain legitimacy for their actions and existence by projecting themselves to be socially responsible.

In the literature, the results regarding the association between firm size and environmental disclosure are mixed. Some studies (e.g., Cormier \& Morgan, 2004; Naser et al., 2006; Ho \& Taylor, 2007; Stammy \& Ely, 2008; Alarussi et al., 2009; Prado-Lorenzo et.al., 2008; Prado-Lorenzo et.al., 2009; Suttipun \& Standton, 2011; Setyorini \& Ishak, 2012; Akrout \& Othman, 2013) found a positive association, although (Davey, 1982; Ng, 1985; Roberts, 1992; Barako et al. 2006; Smith et al. 2007; Prado-Lorenzo et al. (2009) did not find such a relationship.

Based on the above discussion and following the legitimacy theory, it's expected that large firms will disclose more social and environmental information than smaller firms. Therefore, the following hypothesis is tested. 
H1: Companies with greater size disclose more extant of environmental information on their annual report than companies with smaller size.

\section{Profitability}

Deegan, (2002) stated that, legitimacy theory hypothesize that companies are bound to an unwritten social contract within the society where they operate. Failure to comply with their legitimacy will threaten companies' performances and survival. Therefore, more profitable companies can be expected to disclose more voluntary social and environmental information than non-profitable companies. However, the relationship between corporate financial performance and corporate environmental disclosure is arguably one of the most controversial issues yet to be solved (Choi, 1998). The results of different studies measuring the relationship between corporate financial performance and corporate environmental disclosure show mixed results. An association between profitability and social responsibility disclosure has been demonstrated in a number of empirical studies (e g., Smith et al., 2007; Janggu et al., 2007; Akrout and Othman, 2013). However, Cormier and Magnan (2004) documented a weak association between corporate social disclosure and profitability, while (Connelly and Limpaphayon, 2004;Smith et al., 2007; Gil-Estallo et al. 2009; Rahman et al., 2010) found no significant relationship between profitability and corporate social responsibility disclosure. Roberts (1992) have found a positive relationship between lagged profits and corporate social disclosures. To determine the relationship between profitability and the extent of social and environmental information disclosure on annual report, the following hypothesis is tested.

H2: Companies with higher financial profitability disclose more extant of environmental information than companies with lower profitability.

\section{Listing Age}

Under legitimacy theory, companies' societal existence depends on the acceptance of the society where they operate. Since the companies can be influenced by, and have influences to the society, legitimacy is assumed an important resource determining their survival (Deegan, 2002). Therefore, older companies with longer societal existence may have taken relatively more legitimacy and may have a higher reputation and involvement of social responsibility than younger companies.

There is a general notion that older companies disclosure more information than new once. This may be because of the tact that older companies are well established $\&$ are aware of the benefits of elaborated disclosure. Companies listed in the capital market earlier have more experiences to disclosure information considering the reaction of market for appropriate disclosure. As a result the level of disclosure of listed companies significantly influenced by their capital market listing status. Further, Previous studies support the significant association between age of firm and environmental information disclosure (e. g. Roberts, 1992; Alsaeed, 2006; Yang, 2009). Based on the above discussion, it might be expected that the longer a company has been listed on the Stock Exchange, the more likely the company would disclose social and 
environmental information. Therefore, the following hypothesis is tested.

H3: Companies with higher listing age on CSE disclosure more extant of environmental information than companies with lower listing age.

\section{Methodology}

\section{Data and Study Sample}

The population for the study was all the manufacturing companies listed on Colombo Stock Exchange (CSE). Thirty listed manufacturing companies were selected as the sample of study using convenient sample. Annual reports in the financial year 2012/2013 of each company were used as the document to be analyzed to understand the environmental disclosure practices of each company. Annual reports have been used widely in the analysis of corporate social reporting analysis by various authors for their credibility (Kuasirikun et al, 2004, Tilt, 1994). Annual reports are useful to various stakeholders in obtaining information about company performance (Deegan and Rankin, 1997), are published regularly (Neimark, 1992) and provide considerable information on social disclosures (Gray et., al, 1995a).

Content analysis was used to gather the data from annual reports. Abbot and Monsen (1979) defined content analysis as "A technique for gathering data that consist of codifying qualitative

information in anecdotal and literary form into categories in order to derive quantitative scales of verifying levels of complexity..
It is a dominant method used to examine environmental disclosures in annual reports (Gray et.al., 1995b).

\section{ariables and Measures}

The dependent variable in the model is the level of environmental information disclosure on annual report of Sri Lankan listed manufacturing companies. The level of is measured by word count using a checklist divided into 22 different items adopted from previous studies by Wiseman (1992) and Singh \& Ahuja (1983) Deegan and Gordon, (1996). The present study has taken 18 items from these 22 items. The checklist as follows:

1. Past and current expenditure for pollution control equipment and facilities.

2. Future estimates of expenditures for pollution control equipment and facilities.

3. Financing for pollution control equipment or facilities.

4. Air emission information.

5. Water discharge\& conservation information.

6. Solid waste disposal information.

7. Compliance status of facilities.

8. Environmental policies or company concern for the environment.

9. Recycling plant of waste products.

10. Installation of effluent treatment plant.

11. Installation of effluent treatment plant.

12. Anti-litter and conservation campaign.

13. Land reclamation and forestation programmers. 
14. Pollution control of industrial process.

15. Research on new methods of production to reduce environmental pollution.

16. Energy conservation.

17. Raw materials conservation.

18. Support for public or private action designed to protect the environment.

The three independent variables, firm size, profitability and firm's listing age, are the used to achieve the objectives of this study. The variables used in this study were measured on the basis of following:

1) Firm size was measured as the companies' 2012/2013 total of assets.

2) Profitability was measured as the net profit margin of companies' 2012/2013.

3) Firm's listing age (the age of the Sri Lankan companies) were measured in years from the date of incorporation to the end of the 2012 financial year, which for most of the companies was 31 December 2012.

\section{Model Development}

To determine the influence of the three firm characteristics on the level of environmental disclosure the following multiple regression model is developed and fitted to the data.

TSEDI $=\beta_{0}+\beta_{1}$ Size $+\beta_{2}$ Profit $+\beta_{3}$ Age $+\varepsilon$

Where,

TSEDI = Total score of environmental disclosure index

Size $\quad=$ Total assets

Profit $=$ Net profit margin

Age $\quad=$ No of years of the companies listed in the CSE

$\mathbf{E}=$ the error term

\section{Results}

Table 1 shows the distribution of disclosure level of environmental information measured by the word count in percentages of the total of 18 item.

Table 1 Disclosure Levels (The Average Word Count in Environmental Disclosures)

\begin{tabular}{c|c|c|c} 
& & & \\
Score range & No of company (N) & Company (\%) & Cumulative \\
& & & \\
\hline $0-20$ & 1 & 3 & 3 \\
\hline $20-30$ & 5 & 17 & 20 \\
\hline $30-40$ & 4 & 13 & 33 \\
\hline $40-50$ & 2 & 7 & 40 \\
\hline $50-60$ & 5 & 17 & 57 \\
\hline $60-70$ & 11 & 37 & 97 \\
\hline $70-80$ & 1 & 3 & 100 \\
\hline $80-90$ & 1 & 3 & 100
\end{tabular}




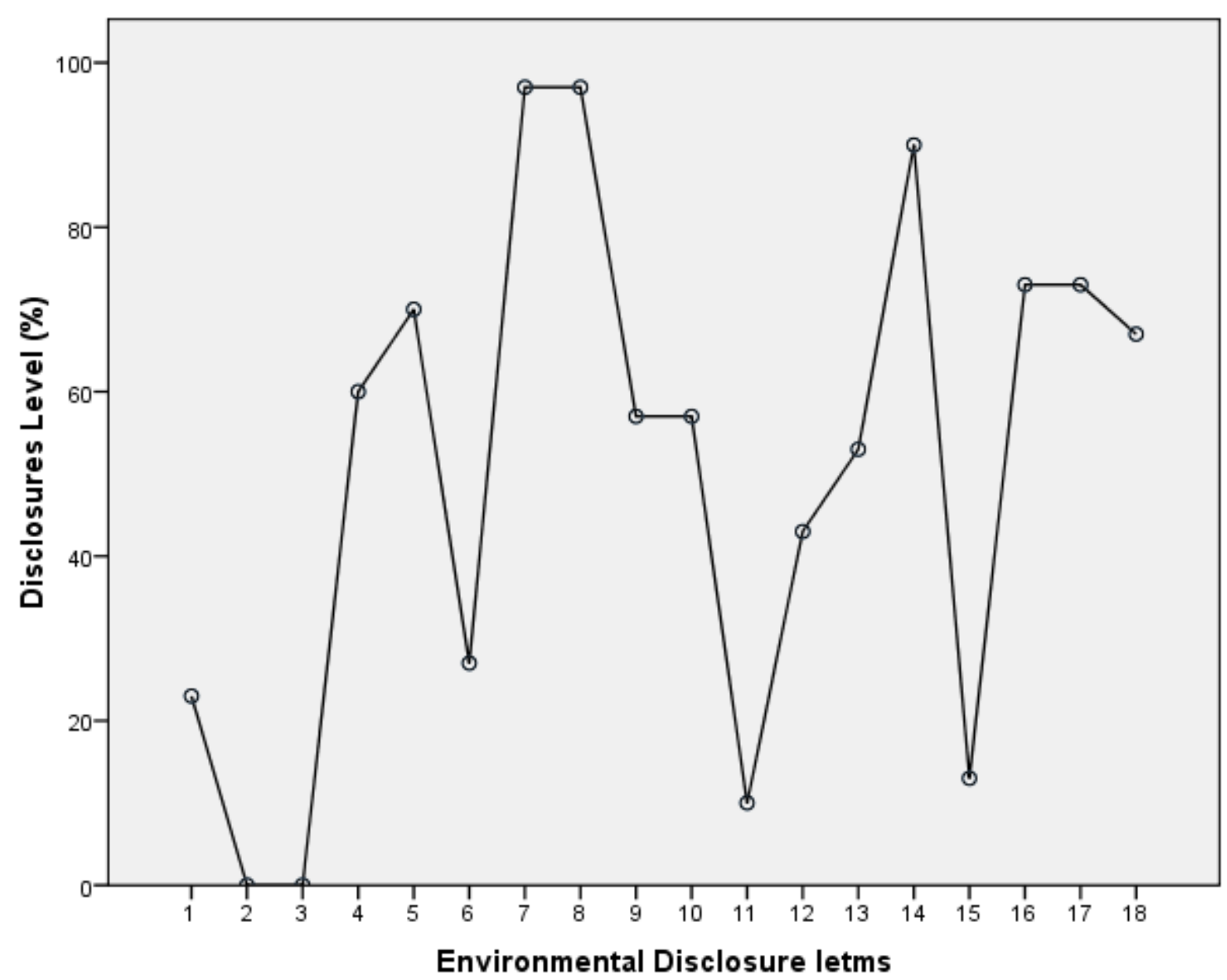

Figure 4.2 Disclosure Levels of each Disclosure Items

Column one of the table 1 shows distinguishes the ranges of level of environmental disclosure in the 18 items. Out of 30 companies 11 companies' corporate environmental disclosure level is laid between 60 to 70 percent. The table 1 also shows that around 80 percent of the sample companies are laid on the level of 20 - 70 percent disclosure items. It implies that the extant of corporate environmental disclosure of manufacturing companies listed on CSE in Sri Lanka is moderate.

Figure 1 shows that companies disclosure of each corporate environmental disclosure items in sample companies' annual reports. According to this figure, it can be seen as most companies are reported about environmental policies or company concern for the environment compliance status of facilities from the environmental disclosure items as 97 percentages (29 of sample companies). The lowest level of corporate environmental disclosure items are future estimates of expenditures for pollution control equipment and facilities and financing for pollution control equipment or facilities. There was no any sample manufacturing companies which disclosure these two items could be found.

The line chart shows that 90 percentages of manufacturing companies (27 companies) disclosure that pollution control of industrial process. 22 companies (73\%) disclosed by energy conservation and Raw materials conservation in their companies annual reports. 
Table - 2: Descriptive Statistics

\begin{tabular}{|l|c|c|c|c|c|}
\hline & $\mathrm{N}$ & Minimum & Maximum & Mean & Std. Deviation \\
\hline TSEDI & 30 & 17 & 89 & 50.63 & 18.0009 \\
\hline Size & 30 & .19 & 78.25 & 13.0763 & 16.53134 \\
\hline Profit & 30 & -28.97 & 90.36 & 8.4747 & 18.12268 \\
\hline Listing Age & 30 & 13 & 81 & 32.27 & 15.550 \\
\hline Valid N (list wise) & 30 & & & & \\
\hline
\end{tabular}

Out of 30companies, 21 companies (70\%) and 20 companies $(67 \%)$ disclosed about Water discharge \& conservation information and Support for public or private action designed to protect the environment respectively on their reports. Other all sample manufacturing companies disclosure less than 20 corporate environmental disclosure items. Very few number of companies have disclosed about Installation of effluent treatment plant and Research on new methods of production to reduce environmental pollution. The results shows that $10 \%$ (3 companies) and 13\% (4 companies) respectively.

According to the study it can be seen air emission information, conservation of natural resources, recycling plant of waste products, land reclamation and forestation programmers and anti-litter and conservation campaign are disclosed moderately. The percentages are between from 50 to 60 . Out of 30 companies 8 companies (27\%) recognized reported in their annual reports about Solid waste disposal information and 7 companies (23\%) recognized reported on their annual reports about Past and current expenditure for pollution control equipment and facilities.

Table 2 show the descriptive statistical tests results of dependent and independent variables for the sample of companies. The table presents the minimum, maximum, mean, and standard deviation for all variables in the regression model. According to the descriptive results the extent of social and environmental information

Table - 3 : Correlations Coefficient between Variable

\begin{tabular}{|c|c|c|c|c|c|c|}
\hline & & & TSED & Size & Profit & Listing Age \\
\hline TSED & Pearson Correlation & Sig. (1-tailed) & 1 & & & \\
\hline Size & Pearson Correlation & Sig. (1-tailed) & $\begin{array}{r}.380 * \\
.019\end{array}$ & 1 & & \\
\hline Profit & Pearson Correlation & Sig. (1-tailed) & $\begin{array}{l}.163 \\
.195\end{array}$ & $\begin{array}{r}-.069 \\
.358\end{array}$ & 1 & \\
\hline Listing Age & Pearson Correlation & Sig. (1-tailed) & $\begin{array}{r}-.123 \\
.259\end{array}$ & $\begin{array}{l}.137 \\
.235\end{array}$ & $\begin{array}{r}-.086 \\
.327\end{array}$ & 1 \\
\hline
\end{tabular}

*Correlation is significant at the 0.05 level (1-tailed). 
disclosure on annual of Sri Lankan listed companies on average is $5.63 .63 \%$ words, and the range of the environmental disclosure is from $17 \%$ to $89 \%$ with standard deviation 18.00. The result indicates that none of the companies disclose all the human resource accounting information items determined in this study. Moreover, the corporate environmental disclosure of manufacturing companies in Sri Lanka is moderate level.

Table 3 presents correlations coefficients between all variables. The results show that there is a significant moderate positive relationship between size and level of environmental disclosure

$(\mathrm{r}=0.380), \quad$ a significant week positive correlation between profitability and level of environmental disclosure $(r=0.163)$ and $a$ significant week negative correlation between listing age and level of environmental disclosure $(r=-0.123)$.

The main results of this study are summarized in tables 4 and 5. The $\mathrm{R}^{2}$ and Adjusted $\mathrm{R}^{2}$ and F-value for the model are presented in tables 4 and 5. The coefficient of determination $\left(\mathrm{R}^{2}\right)$ under the model was .206, which indicates that the model is capable of explaining $20.6 \%$ of the variability of the disclosure of social and environmental information in the sample Sri Lankan companies under study. The adjusted $\mathrm{R}^{2}$ indicate that $11.5 \%$ of the variation in the dependent variable in the model is explained by variations in the independent variables. The multiple regression model.

Table 5 presents a summary of the multiple regression results for the environmental information disclosure on annual reports of Sri Lankan listed manufacturing companies. Standardized beta coefficients, t-statistics, and probability levels are given for each independent variable in the model. The empirical evidence indicates that there is a significant positive association between at firm size and the level of environmental discoursers $(\beta=.414$, sig $<$ $.05)$ at $5 \%$ significant level. This result support Hypothesis -1, and suggests that Sri Lankan listed manufacturing companies with greater size disclose more environmental information on their annual report than companies with small size. This result is consistent with previous studies (e.g., Cormier and Morgan, 2004; Naser et al., 2006; Ho and Taylor, 2007; Stanny and Ely, 2008; Alarussi et al., 2009; Prado-Lorenzo et.al., 2009a; Prado-Lorenzo et.al., 2009b Suttipun and Standton, 2011; Setyorini and Ishak, 2012; Akrout and Othman, 2013) who found a positive association between firm size and the extant of environmental information disclosures.

Contrary to the expectations, the regression results indicate that there is an insignificant positive association between profit and the level of environmental discoursers $(\beta=.177$, sig

Table 4 Model Summery

\begin{tabular}{|c|c|c|c|}
\hline $\mathrm{R}$ & R Square & Adjusted R Square & Std. Error of the Estimates \\
\hline $.454^{\mathrm{a}}$ & .206 & .115 & 16.943 \\
\hline
\end{tabular}

a. Predictors: (Constant), AGE, NPMARGIN, ASSETS 
Table 5 Multiple Regression Model Result, Coefficient

\begin{tabular}{|c|c|c|c|c|c|c|c|}
\hline & \multirow[t]{2}{*}{ Model } & \multicolumn{2}{|c|}{ Unstandardized Coefficents } & \multirow{2}{*}{\multicolumn{2}{|c|}{$\frac{\text { standardized Coefficents }}{\text { Beta }}$}} & \multirow[t]{2}{*}{$\mathrm{t}$} & \multirow[t]{2}{*}{ Sig. } \\
\hline & & $\mathrm{B}$ & Std.Error & & & & \\
\hline 1 & Constant & 49.38 & 7.703 & 6.411 & 000 & 6.411 & 6.411 \\
\hline & Size & .451 & .192 & & .414 & 2.346 & 2.346 \\
\hline & Profit & .176 & .175 & & .177 & 1.010 & 1.010 \\
\hline & Listing Age & -.1918 & .205 & & -.165 & -.931 & -.931 \\
\hline
\end{tabular}

$>.05)$ at $5 \%$ significant level. This result does not support Hypothesis - 2, and suggests that Sri Lankan listed manufacturing companies with higher financial profitability do not disclose more extant of environmental information than companies with lower profitability. This result is consistent with previous studies (e.g., Connelly and Limpaphayon, 2004;Smith et al., 2007; Gil-Estallo et al. 2009; Rahman et al., 2010) who found no significant relationship between profitability and corporate social responsibility disclosure. Further, the findings revealed that, the other independent variable, listing age, do not appear to be significant and negative in explaining the environmental information disclosures on annual report of Sri Lankan listed manufacturing companies. This finding is in consistent with the finding of previous empirical studies (e. g. Roberts, 1992; Alsaeed, 2006; Yang, 2009) who found a significant relationship between environmental reporting and firms' age.

\section{Conclusion}

The extent of social and environmental disclosures on Sri Lankan listed manufacturing companies' annual report, is measured by word count using a checklist consisting 18 items. To determine the factors that influence the level of social and environmental information disclosures under legitimacy theory, descriptive statistics, correlation analysis and multiple regressions analysis were used. The findings indicate that the sampled listed manufacturing companies provided a moderate level environmental information on their annual report. These disclosures were voluntary in nature and largely qualitative, and the standard deviations indicate that there are wide variations in the level of social and environmental information disclosure between the listed companies and sectors. Multiple regression analysis revealed that there is a highly significant positive association between firm size and disclosure. This result suggests that Sri Lankan listed manufacturing companies with greater size disclose more environmental information on their annual report than companies with smaller size. Also, the regression results indicate that there is an in significant positive association between profit and environmental information disclosure. This result suggests that Sri Lankan listed manufacturing companies with large profit did not disclose more social and environmental information on their annual report than the companies with lower profit. Further, the findings revealed that listing age do not appear 
to be significant and negative in explaining the environmental information disclosures on annual report of Sri Lankan listed manufacturing companies. The results of this study support the legitimacy theory arguments and supported the notion that, legitimacy theory as an explicator for variability in social and environmental disclosures, and firms do voluntarily disclose information in their annual reports as a strategy to manage their legitimacy. Also, this study provides some empirical evidence related to the level and content of social and environmental disclosure for researchers, students, and academics, and it extends the findings of previous studies in developing countries.

\section{Reference}

Abbot,W.F. \& Monsen, R.J. (1979), “On the measurement of corporate social responsibility: self reporting disclosures as a method of measuring corporate social involvement", Academy of Management Journal, Vol. 22 No. 3, pp. 501-15.

Akrout M. M. \& Othman H. B. (2013), “A Study of the determinants of corporate environmental disclosure in MENA emerging markets", Journal of Reviews on Global Economics, Vol. 2, pp. 46-59.

Alarussi, A. S., M. M. Hanefah, \& M. H. Selamat (2009), "Internet financial and environmental disclosures by Malaysian companies", Issues in Social and Environmental Accounting, Vol. 3, No. 1, pp. 3-25

Alsaeed K. (2006), "The association between firm specific characteristics and disclosure", Managerial Auditing Journal.
Barako, D. G., Hancock, P., \& Izan, H. Y. (2006), "Relationship between corporate governance attributes and voluntary disclosures in annual reports: the Kenyan experience", Financial Reporting, Regulation and Governance, Vol. 5, No. 1, pp. 1-25.

Blacconiere, W. G. \& Patten D. M. (1994), "Environmental disclosures, regulatory costs and changes in firm value", Journal of Accounting and Economics, Vol. 18, No. 3, pp. 357-377.

Choi, J. S. (1998), "an evaluation of the voluntary corporate environmental disclosures: a Korean evidence", Social and Environmental Accounting, Vol. 18 No. 1, pp. 2-7.

Connelly, J. T., \& Limpaphayom, P. (2004), "Environmental reporting and firm performance: evidence from Thailand, The Journal of Corporate Citizenship, Vol. 13, pp. 137-149.

Cormier, D T \& Morgan, M (2004), "The impact of the web on information and communication modes: the case of corporate environmental disclosure", International Journal of Technology Management, Vol. 27, No. 4, pp. 393-416.

Cowen, S.S., Ferreri, L.B. \& Parker, L.D. (1987), "The impact of corporate characteristics on social responsibility disclosure: A typology and frequencybased analysis", Accounting, Organisations and Society, Vol. 12, No. 2, pp. 111-22. 
Davey, H. B. (1982), “Corporate social responsibility disclosure in New Zealand: an empirical investigation, Unpublished Working Paper, Massey University, Palmerston North, New Zealand.

Deegan, C. \& Rankin M. (1996), “Do Australian companies report environmental news objectively? An analysis of environmental disclosures by firms prosecuted successfully by the environmental protection authority", Accounting, Auditing and Accountability Journal, Vol. 9, No. 2, pp. 50-67.

Deegan, C (2002), "Introduction: the legitimizing effect of social and environmental disclosures - a theoretical foundation", Accounting, Auditing and Accountability Journal, Vol. 15, No. 3, pp. 282-311.

Deegan, C. M. (2007), "Financial Accounting Theory ( $2^{\text {nd }}$ ed.), Australia: McGraw-Hill.

Deegan, C. \& Gordon, B. (1996), “A study of the environmental disclosure practices of Australian corporations", Accounting of Management Review, Vol. 20, pp. 65-91

Deegan, C. \& Ranki, M. (1997), “The materiality of environmental information to users of annual reports", Accounting, Auditing and Accountability Journal, Vol. 10, pp. $562-583$

Eilbert, H.\& Parket, I.R. (1973), "The current status of corporate social responsibility",

Business Horizons, 16, 5-14.

Gil-Estallo, Maria de- los- Angeles, Ginerde-la-Fuente, F. and Griful-Miquela, C. (2009),
"Benchmarking corporate social responsibility within Spanish companies", International Advance Economic Research, Vol. 15, pp. 207-225.

Gray, R., Kouhy, R. \& Lavers, S. (1995a), "Methodological themes: constructing a research database of social and environmental reporting by UK companies", Accounting, Auditing and Accountability Journal, Vol. 8, No. 2, pp. 78-101.

Gray, R., Kouhy, R. \& Lavers, S. (1995b), "Corporate social and environmental reporting", Accounting, Auditing and Accountability Journal, Vol. 8, No. 2, pp. 47-77.

Guthrie, J. \& Parker L. (1989), “Corporate social reporting: a rebuttal of legitimacy theory", Accounting and Business Review, Vol. 19, No.3, pp. 343-352.

Guthrie, J., \& Parker, L. (1990), “Corporate social disclosure practice: a comparative international analysis", Advances in Public Interest Accounting, Vol. 3, pp. 159-176.

Hackston, D., \& Milne, M. J. (1996), "Some determinants of social and environmental disclosures in New Zealand companies", Accounting, Auditing and Accountability Journal, Vol. 9, No. 1, pp. 77-108.

Hogner, R. H. (1982), "Corporate social reporting: eight decades of development at U.S. steel', Research in Corporate Social Performance and Policy, Vol. 4, pp. 243250. 
Ho, L.-C. J. \& M. Taylor, E. (2007), “An empirical analysis of triple bottom-line reporting and its determinants: evidence from the United States and Japan", Journal of International Financial Management \& Accounting, Vol. 18, No. 2, pp. 123-150.

Janggu, T, Joseph, C.\& Madi, N. (2007), The current state of corporate social responsibility among industrial companies in Malaysia”, Social Responsibility Journal, Vol. 3, No. 3, pp. 9-18.

Kuasirikun, N., \& Sherer, M. (2004), "Corporate social accounting disclosure in Thailand", Accounting, Auditing and Accountability Journal, Vol. 17, pp. 629660.

Lindblom, C.K. (1983), “The concept of organizational transitions and transformations: some alternative models", Working Paper, Vol. 12, No. 2, pp. American Accounting Association Public Interest Section.

Naser, K., Al-Hussaini, A., Al-Kwari,D \& Nuseibeh, R. (2006), "Determinants of corporate social disclosure in developing countries: the case of Qatar", Advances in International Accounting, Vol. 19, pp. $1-23$.

Neimark, M.K. (1992), “The hidden dimension of annual reports: sixty years of social conflicts at General Motors, Markusweiser Publishing, New York, N.Y.

Neu, D., Warsame H. \& Pedwell K. (1998), "Managing public impressions: environmental disclosures in annual reports", Accounting, Organizations and Society, Vol. 23, No. 3, pp. 265-282.
Patten, D.M. (1991), "Exposure, legitimacy and social disclosure", Journal of Accounting Public Policy, Vol. 10, No. 1, Spring, pp. 297-308.

Patten, D.M. (1992), "Intra-industry environmental disclosures in response to the Alaskan Oil Spill: a note on legitimacy theory", Accounting, Organizations and Society, Vol. 17, No. 5, pp. 471-475.

Patten, D. M. (2002), “The relation between environmental performance and environmental disclosure: a research note", Accounting Organizations and Society, Vol. 27, pp. 763-773.

Perrow, C. (1970), Organizational analysis: A sociological view (Wadsworth, Belmont, CA).

Prado-Lorenzo, J.-M., I. Gallego-Alvarez \& I. Garcia-Sanchez, M. (2009), "Stakeholder engagement and corporate social responsibility reporting: the ownership structure effect." Corporate Social - Responsibility and Environmental Management, Vol. 16, No. 2, p. 94.

Prado-Lorenzo, J., Gallego-Alvarez, I., GarciaSanchez, I. \& Rodriguez-Dominguez, L.

(2008), "Social responsibility in Spain: practices and motivation in firms", Management Decisions, Vol. 46, pp. 1247-1271.

Rahman, S. A., Yusoff, R. B., \& Mohamed, W. N. (2010), "Environmental disclosures and financial performance: an empirical study of Malaysia, Thailand, and Singapore", Social and Environmental Accountability Journal, Vol. 29, No. 2, pp. 46-58. 
Richardson A. J., \& Welker M. (2001), "Social disclosure, financial disclosure and the cost of equity capital", Accounting, Organizations and Society, Vol. 26, No. 7, pp. 597-616.

Roberts, R.W. (1992), "Determinants of corporate social responsibility disclosure: an application of stakeholder theory", Accounting, Organizations and Society, Vol. 17, No. 6, pp. 595-612.

Setyorini, C. T. \& Z. Ishak, (2012), “Corporate social and environmental disclosure: a positive accounting theory view point", International Journal of Business and Social Science, Vol. 3, No. 9, pp. 152-164.

Singh D. R. \&Ahuja J.M. (1983), “Corporate social reporting in India", International Journal of Accounting Education and Research.

Smith, M, Yahya, K \& Amiruddin, AM (2007), "Environmental disclosure and performance reporting in Malaysia", Asian Review of Accounting, Vol. 15, No. 2, pp. 185-199.

Stammy, E. \& Ely, K. (2008), "Corporate environmental disclosures about the effects of climate change", Corporate Social-Responsibility and Environmental Management, Vol. 15, No. 6, pp. 338-352
Suttipun,M.,\&Stanton,P.(2011), “Determinates of environmental reporting in corporate annual reports of the Stock Exchange of Thailand (SET)", International Journal of Accounting and Financial Reporting, Vol. 2, No. 1, pp. 99-115.

Tilt, C.A. (1994), “The influence of external pressure groups on corporate social disclosures: Some empirical evidence", Accounting, Auditing and Accountability Journal, Vol. 7, 47-72.

Villiers, C. D., \& Van Staden, C. J. (2011), "Where firms choose to disclose voluntary environmental information", Journal of Accounting and Public Policy, Vol. 30, No. 6, pp. 504-525.

Wiseman, J. (1982), "An Evaluation of environmental disclosures made in corporate annual reports", Accounting, Organizations and Society, Vol. 7, No. 1, pp. 53-63.

Woodward, D., Edwards P.\& Birkin F. (2001), "Some evidence on executives' views of corporate social responsibility", British Accounting Review, Vol. 33, No. 3, pp. 357-397.

Yang, C. F. (2009), "Empirical study on the influential factors of social responsibility of Chinese enterprises", The Economists, pp. 69-79. 